\title{
ORGANIZING LEISURE TIME IN A FAMILY FOR ELEMENTARY SCHOOL CHILDREN IN THE CONTEXT OF HEALTH EDUCATION
}

\author{
Neringa Strazdiene் ${ }^{1}$, Birutė Strukčinskien $\dot{e}^{1}$, Alona Rauckienė-Michaelsson ${ }^{1}$, \\ Sigitas Griškonis ${ }^{1,2}$ \\ ${ }^{1}$ Klaipeda University, ${ }^{2}$ Klaipeda University Hospital, Lithuania
}

Key words: elementary school children, leisure time, health education, family.

\begin{abstract}
Summary
Children leisure time is usually decided by their immediate environment, i.e. their family. Therefore, leisure activities which are designed in a family and which enable children to discover pleasant experiences and motivate them to care of their own health are of extreme importance. The aim of the study was to highlight the peculiarities of the organization of leisure time activities in a family for elementary school students in the context of health education. The respondents of the study were 614 elementary school students from eight Western Lithuania schools and 604 of their parents. The study has shown that elementary school students rate their health more favourably than their parents. Almost half of the respondents-children $(42.7 \%)$ have rated their health as very good and around the same number of children $(45.3 \%)$ have rated it as good. One fifth of respondents-parents $(20.7 \%)$ have rated the health of their children as very good and more than half of parents $(62.3 \%)$ have said that the health of their children is good. The opinion of parents and their children on the issue of the time allocated for leisure activities has been discovered as being similar. Respondentschildren indicate that on weekdays their leisure time averages to 2.4 hours/day and at the weekends to 4.3 hours/day. Respondents-parents indicate that children's leisure time on weekdays lasts for 2.2 hours/ day, and at the weekends it reaches 4.4 hours /day. It has been revealed that the longer the leisure time the children have, the better their health is. The majority of children (78\%) believe that they have enough leisure time. Those, who assume that they do not have enough leisure time, and those, who are undecided, make almost one-fourth (24\%). A third of elementary school students enjoy physically active forms of leisure time activities (going in for sports) while about a half of respondents-children prefer passive forms
\end{abstract}

of leisure time activities (artistic activities, watching $\mathrm{TV}$, playing computer games, reading books). Respondents-children point out that they devote on average 3.4 hours/day for passive forms of activities and 2.2.hours/day for physical active leisure activities. Their parents state that children spend 4.3 hours /day for passive activities and 1.8 hours/day for physical active leisure activities. Only about one-tenth of families engage themselves in mutual active forms of physical activities and play sports together. Therefore, the leisure time spent by children together with the family is not sufficiently active.

\section{Introduction}

Involvement of children into leisure activities is extremely significant in the development of health education, processes of maturity, socialization, and takeover of culture and values. The right of children to leisure is enshrined in the United Nations Convention on the Rights of the Child. It recognizes the child's right to rest and leisure, participation in games and entertainment events appropriate for his or her age, cultural life, etc. [1]. Scientists note that the key leisure time objective in the social system is to guarantee leisure time quality, which would enable the development of the child's diversified skills and competencies and would enhance his or her integration into society, and adaptation to rapid and constant changes [2].

With the development of information technologies, passive forms of leisure activities are becoming a problem not only for adults, but also for children [3]. Children's leisure usually depends on their nearest environment - the family, educational institutions, and other organizations [4]. Therefore, the family planning and arrangement of leisure activities, which help children to find pleasant and useful forms of their free time and which motivate to care about their health, are of great importance [5].

The aim of the study is to highlight the peculiarities of the organization of leisure time activities in a family for elementary school students in the health education context. 


\section{Materials and Methods}

The written questionnaire as a quantitative research method has been chosen. The questionnaire was conducted in 2016. Schoolchildren of year two to year four (aged 8 to 11 years) $(56.8 \%$ of girls and $43.2 \%$ of boys) were surveyed in eight general education schools of Western Lithuania. The study involved 614 elementary school students. In addition, 604 parents of these students were interviewed too. The targeted parents' sample was dominated by women $(90.40 \%)$. About half of the parents $(54.0 \%)$ were at the age of 31 to 40 , about a third (38.4\%) were 41 to 50 years old. A small part of the parents questioned were from 21 to 30 years old and 51 to 60 years old ( $1.6 \%$ and $6.0 \%$ respectively).

The data was processed by SPSS (version 21.0). The Pearson correlation coefficient was applied to the study. The data was statistically significant at $\mathrm{p} \leq 0.05$.

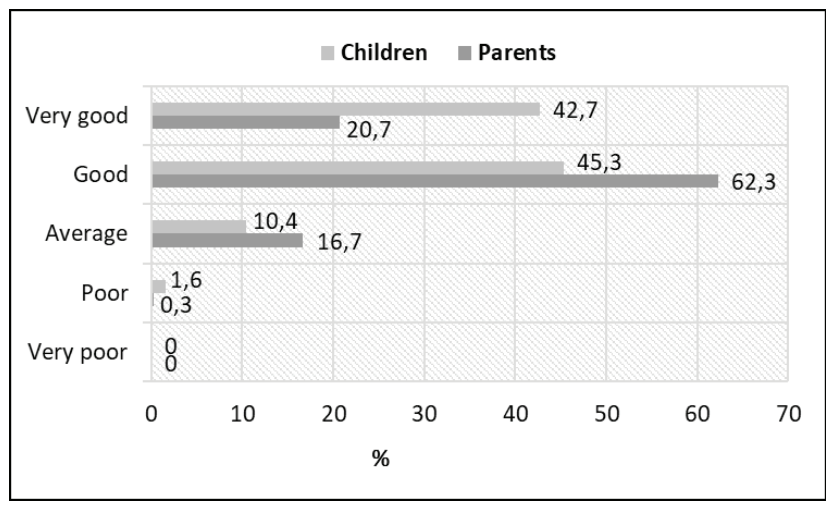

Figure 1. Assessment of children's health (opinions of respondentschildren and respondents- parents)

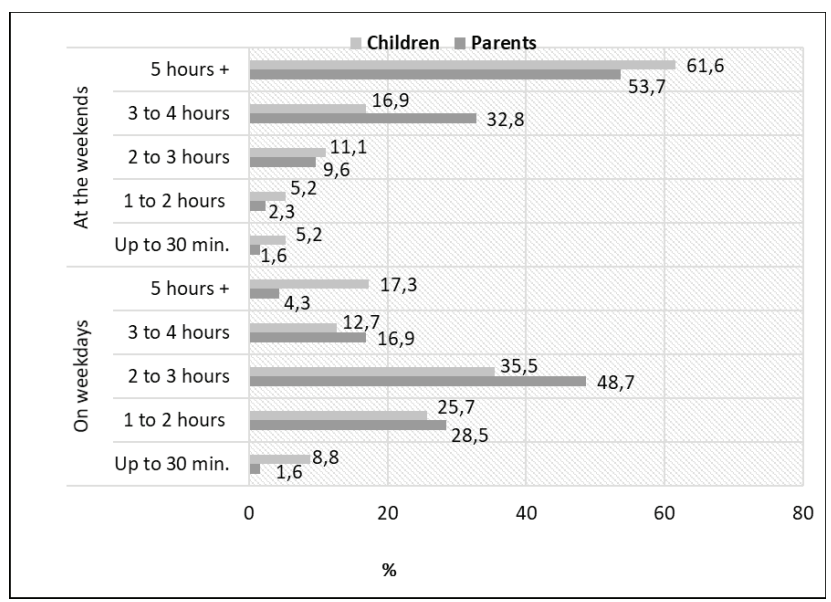

Figure 2. Length of elementary school children's leisure time (responses provided by children and their parents)

\section{Results and Discussion}

Elementary school children were asked to assess their own health and their parents were asked to assess the health of their children (Figure 1).

The respondents-children have assessed their health more favourably than their parents. $42.7 \%$ of children have described their health as very good and $45.3 \%$ of children said that their health is good. Respectively, $20.7 \%$ of respondentsparents have assessed the health of their children as very good and $62.3 \%$ thought that it is good. $10.4 \%$ of children and $16.7 \%$ of their parents described the children's health as average.

The study also tried to figure out the length of elementary school students' leisure time on weekdays and at the weekends (responses provided by children and their parents) (Figure 2).

Almost half of the respondents-children (48.7\%) enjoy 2 to 3 hours leisure time on weekdays, while at the weekend the time allocated for leisure is longer and extends to 5 and more hours (53.7\%). The respondents-parents' responded that the average length of leisure time on weekdays reaches

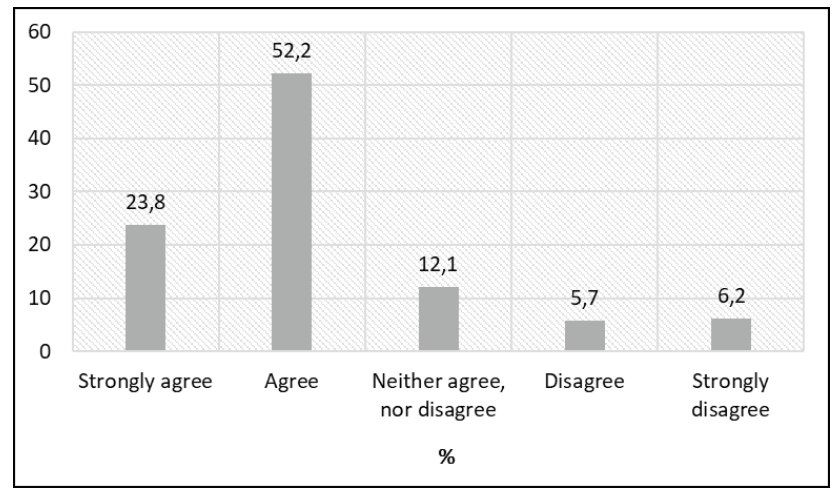

Figure 3. Children's opinion on whether they have enough free time

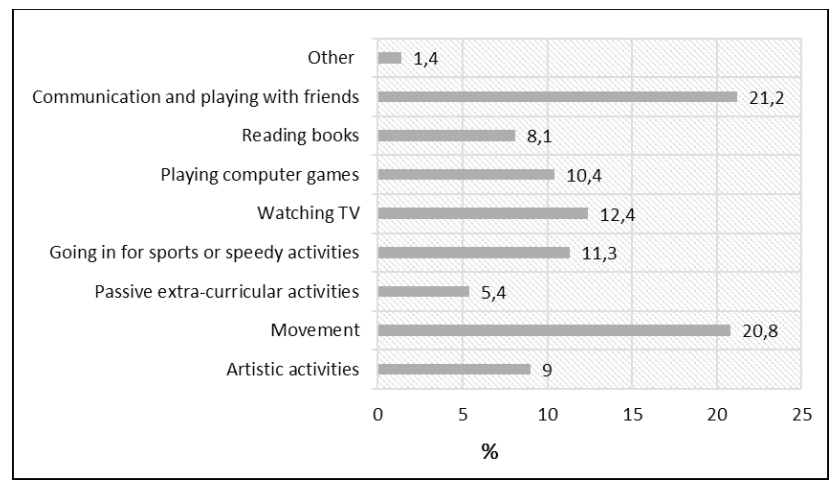

Figure 4. Leisure activities preferred by children (the opinion of children) 
2.2 hours, and at the weekends it extends to 4.4. hours. Children's opinions on the length of their leisure time are similar to those of their parents. The average scores of both groups of respondents are relatively close. It has been established that in the opinion of respondents-children their leisure time on average is 2.4 hours/day on weekdays, while at the weekends it is 4.3 hours.

With reference to the relationship between health assessment and time allocated for leisure and indicated by children themselves, statistically significant positive correlation between health assessment and time allocated for leisure has been identified: on weekdays $(r=0.213 ; \mathrm{p}<0.001)$ and at weekends $(r=0.450 ; p<0.001)$. Thus, the conclusion can be drawn that longer leisure time is associated with better health of children, while shorter leisure time is associated with more poor health of children.

Respondents-children have also been asked whether in their opinion they have enough free time. Majority of elementary school students (78.0\%) strongly agree or agree with the statement that they have enough free time. Those who are undecided or believe that they do not have enough free time make about one fifth of the total number of respondents-children (24.0\%) (Figure 3).

Child-friendly activities motivate them to action and stimulate positive emotions. Therefore, the research aimed to find out what kind of leisure activities are mostly preferred by elementary education students (Figure 3 ).

About one third of elementary school students (32.1\%) state that they enjoy physical activities: $20.8 \%$ of children like to move and $11.3 \%$ of children enjoy going in for sports and other forms of exercise. The study has also shown that nearly half of respondents-children (45.3\%) prefer passive forms of different activities: artistic activities (9.0\%), passive extra-curricular activities (5.4\%), watching TV (12.4\%),

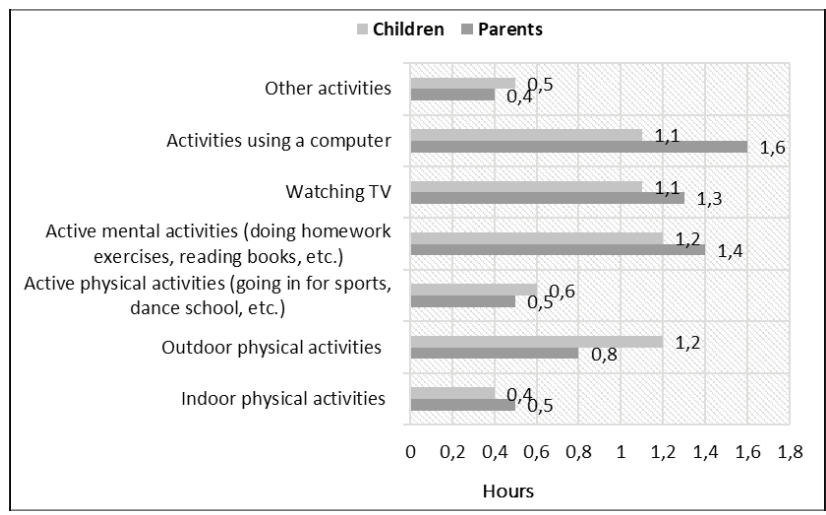

Figure 5. Time allocated for different elementary school students' activities (opinions of respondents-children and respondents-parents) playing computer games $(10.4 \%)$, and reading books $(8.1 \%)$.

With reference to elementary school students' day-to-day routine, the ratio between physical activities and passive forms of activities becomes of extreme importance. Respondents-parents have been asked to indicate how much time is allocated for different activities of their children a day, including extra-curricular activities (Figure 5). The results obtained are the following: passive activities take on average 3.4 hours/day (opinion of respondents-children) and 4.3 hours/day (opinion of respondents-parents). Active physical activities usually take 2.2 hours/day (children's opinion) and 1.8 hours/day (parents' opinion). Thus, with reference to opinions expressed by children and their parents statistically significant correlation has not been identified between the average time allocated for different activities and self-reported children's health.

Family lifestyle, ways of spending leisure and free time, as well as parental influence play an important role in the developmental process of children's habits, how to spend their leisure and free time, and in the development of their personal lifestyles as future adults. Therefore, the study has also looked into the question of how the families of the respondents spend their leisure time (Figure 6).

The most popular family leisure activities are: spending time in nature (children - $17.0 \%$, parents - $19.2 \%$ ), entertainment in shopping and entertainment centres (children - $16.7 \%$, parents $-15.9 \%$ ), watching TV shows and movies together (children - $16.5 \%$, parents - 14.4\%), visiting friends (children $-15.9 \%$, parents $-15.0 \%$ ). Only about one-tenth of families engage in active physical activities and play sports together (children $-7.0 \%$, parents $-11.7 \%$ ).

The study suggests that decisions on the choice of forms for leisure activities in the families should be done taking into account the preferences expressed by children. The sta-

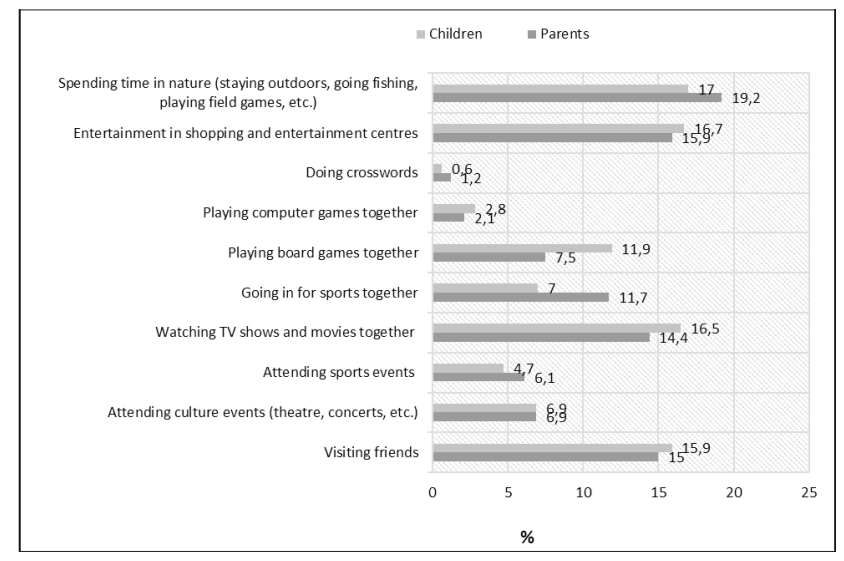

Figure 6. Family leisure time activities (opinions of children and their parents) 
tement, whether family members in deciding on the choice of forms of leisure activities take into account child preferences was answered by respondents-children in the following way: Strongly agree $-24.4 \%$, Agree $-56.7 \%$. The answer option Disagree was chosen by $13.7 \%$ of respondents-children, and the answer Strongly disagree was chosen by $2.0 \%$ respondents-children. The remaining $3.2 \%$ of respondents-children stayed undecided on this issue.

Children leisure activities are preconditioned by their natural needs to be active, independent, and initiative. The results of the study on the organization of leisure activities in the family for Western Lithuania elementary school students in the context of health education have led to identification of the leisure activities according to the natural needs of children. It has been recognised that in their leisure time children engage in a variety of activities: artistic activities, different movement activities (playing active games, moving outdoors), participation in passive extra-curricular activities (music, theatre, painting), going in for sports (basketball, dancing, swimming), watching TV, playing computer games, reading books, and playing with friends.

About a third of elementary school students have stated that they enjoy physically active leisure activities (movement and attendance of sports clubs), while almost half of respondents-children prefer passive forms of leisure activities (artistic activities, participation in passive extra-curricular activities, watching TV, playing computer games, and reading books). The studies conducted by other scientists $[6,7]$ demonstrate that the most favourable leisure time activities for children are playing with friends and watching TV.

The results of the study have revealed the logically justified relationship between health assessment and leisure time indicated by children. Although majority of elementary school students $(78.0 \%)$ strongly agree or agree with the statement that they have enough free time, the study has also highlighted the situation that better health of children is associated with longer leisure time. Thus, not only the length of leisure time but also the understanding of its quality with reference to health promotion and health education become the key potential of educational activity.

The study conducted by R. Sketerskiene and others [7] showed that $60.3 \%$ of school students usually watch TV for 2-3 hours a day and $30.7 \%$ of children spend 2 or more hours on the computer. R. Stukas and others [8] stated in their study that majority of children watch TV 1-2 hours a day, a fifth of children watch TV 2-3 hours a day, and 3\% of children do not watch TV at all. The study conducted by L. Dregval and others [9] exhibited that two-fifths of elementary school students spend 1-2 hours a day on the computer. The results gained by the present survey are very similar: elementary school students spend 1.1 hours a day on the computer in the opinion of respondents-children and 1.6 hours a day in the opinion of respondents-parents. Watching TV lasts for 1.1 hours a day in the opinion of respondents-children and 1.3 hours in the opinion of respondents-parents.

The content of children leisure time, its planning and organization is the duty and responsibility of their parents [10]. The organization of leisure activities for children not only has to be targeted to the achievement of certain goals. It also has to focus on the health of children and their preferences as regards the choice of leisure activities. This is a prerequisite for the safety and freedom of the child [11]. The outcomes of our research have shown that the majority of families follow this provision. However, $15.7 \%$ of families ignore children's preferences when choosing leisure activities.

The active lifestyle of parents, their participation in sports and fitness events is of great significance in tailoring the activity lifestyle of their children [12]. The present research has revealed that only a minority of families engage in active physical activities with their children. The study conducted by Adaskeviciene E. and Strazdiene N. revealed that 57.4\% of parents have never attended sports and fitness events at school of their children and $88.9 \%$ of parents have never assisted teachers in arranging such events at school [12]. Thus, more attention should be paid to the organization of leisure activities for children in the family, to the development of parental competencies, and to the expansion of the range of active leisure activities. The school community should be able to support the families. In addition, health policy makers, municipality health departments, public health bureaus, and non-governmental organizations should be actively involved in solutions of these problems. National and international health promotion strategies, projects and programmes for children and families need for healthy lifestyle formation in family setting.

\section{Conclusions}

1. Elementary school students have rated their health more favourably than their parents. Almost half of the respondents-children strongly agreed that their health is good. Around the same number of children agreed that their health is good. A fifth of respondents-parents rated their children's health as very good and more than half of them stated that it is good.

2. Children and their parents' attitudes towards the length of children's leisure time have been similar. In the opinion of respondents-children on weekdays, their leisure time lasts for 2.4 hours a day, and at weekends it is 4.3 hours a day. In the opinion of respondents-parents, the free time of their children on weekdays lasts for 2.2 hours a day and at 
weekends it is 4.4 hours a day. It has been revealed that the longer leisure time children have the better their health is. Majority of children think that they have enough free time. Those who think that they do not have enough free time and those who are undecided make almost one-fourth of the respondents-children.

3. A third of elementary school students enjoy physically active leisure activities (movement and going in for sports) and around half of the respondents-children prefer passive forms of activities (artistic activities, passive extra-curricular activities, watching TV, playing computer games, and reading books). In the opinion of the respondents-children, they devote 3.4 hours daily to passive forms of activities while their parents state that their children devote 4.3 hours daily to passive forms of activities. Active physical activities take 2.2 hours a day (opinion of respondents-children) and 1.8 hours a day (opinion of respondents-parents). Only a third of families take part in physical activities and enjoy sports together. Therefore, leisure time that families - children and their parents - enjoy together is not active enough.

\section{References}

1. The United Nations Convention on the Rights of the Child. United Nations. Available at: http://www.ohchr.org/EN/ProfessionalInterest/Pages/CRC.aspx. Accessed: 30/08/2017.

2. Siauciuliene R. Children's summer leisure social, educational, cultural meaning (theoretical aspect). Leisure Research: Electronic Science Journal 2013; 1(1): 1-7.

3. Laskiene S, Zuoziene IJ, Zuoza AK. Analysis of mode of leisure practiced by children of junior school age. Public Health 2009; 1(44): 70-77.

4. Cassidy T. Leisure, coping and health: the role of social, family, school and peer relationship factors. British Journal of Guidance \& Counselling 2005; 33(1), 51-66. https://doi.org/10.1080/03069880412331335830

5. Stellino MB, Sinclair CD. Intrinsically motivated, free-time physical activity: considerations for recess. Journal of Physical Education, Recreation \& Dance (JOPERD) 2008; 79(4): 37-40. https://doi.org/10.1080/07303084.2008.10598162

6. Anastasiadou SD. Measuring trends in leisure: differences and similarities in the allocation of leisure times between indigenous pupils and immigrants in Greek elementary education. The International Journal of Diversity in Organisations, Communities and Notions 2008; 7(6):127-132.

https://doi.org/10.18848/1447-9532/CGP/ v07i06/395047.

7. Sketerskiene R, Surkiene G, Zagminas K. Associations between schoolchildren's educational load and health, and the day's routine. Medicine (Lithuania) 2009; 45(5): 395-404.

8. Stukas R, Kalibatienė D, Vingras A. et al. The lifestyle and health of primary schoolchildren of Vilnius city (Lithuania).
Medical Theory and Practice 2011; 4 (17):430-436.

9. Dregval L, Malinauskaite V. Physical activities of first grade pupils in relation to social economic factors. Education. Physical Training. Sport 2008; 4(71):29-36.

10. Bajoriunaite I, Lukaviciene V. Forms and content of family leisure activities: Children's reflections of their experiences. Social Education VII, 2014; 7: 131-138.

11. Konceviciene N, Berzanskiene M, Eidukaitiene V. Possibilities of leisure of people older than 60 years in Marijampole Region. Management theory and studies for rural business and infrastructure development, 2013; 4(35): 554-563.

12. Adaskeviciene E, Strazdiene N. Education of pupils' physical activity. Monograph. Klaipeda, 2017.

\section{PRADINIU KLASIŲ MOKINIŲ LAISVALAIKIO ORGANIZAVIMAS ŠEIMOJE SVEIKATOS UGDYMO KONTEKSTE}

N. Strazdienė, B. Strukčinskienė, A. Rauckienè-Michaelsson, S. Griškonis

Raktažodžiai: pradinių klasių mokiniai, laisvalaikis, sveikatos ugdymas, šeima, vaikai.

Santrauka

Vaikų laisvalaikis dažniausiai priklauso nuo jo artimiausios aplinkos - šeimos. Taigi šeimoje kryptingai organizuojamas laisvalaikis, padedantis vaikams atrasti malonias veiklas ir motyvuojantis labiau rūpintis savo sveikata, yra ypač svarbus. Darbo tikslas - atskleisti pradinių klasių mokinių laisvalaikio organizavimo ypatumus šeimoje sveikatos ugdymo kontekste. Tyrime dalyvavo 614 pradinių klasių mokiniai iš aštuonių Vakarų Lietuvos mokyklų ir 604 jų tèvai. Nustatyta, jog pradinių klasių mokiniai savo sveikatą vertino palankiau nei jų tẻvai. Beveik pusè (42,7 proc.) vaikų ją vertino kaip labai gerą ir apytiksliai tiek pat (45,3 proc.) vertino kaip gerą. Penktadalis (20,7 proc.) tèvų savo vaikų sveikatą vertino kaip labai gerą ir daugiau kaip puse (62,3 proc.) - kaip gerą. Vaikų ir tėvų nuomonės vaikų laisvalaikio trukmès klausimu buvo panašios. Vaikų nuomone, darbo dienomis vidutiniškai jų laisvalaikis trunka 2,4 val., o savaitgaliais - 4,3 val. per dieną. Tẻvų nuomone, darbo dienomis vaikų savaitgalis trunka - 2,2 val., o savaitgaliais $-4,4$ val. per dieną. Nustatyta, jog ilgesnè laisvalaikio trukmė yra susijusi su geresne jų sveikata. Dauguma (78 proc.) vaikų mano, kad jiems pakanka turimo laisvo laiko, o neapsisprendusių ir manančių, kad jiems nepakanka laisvo laiko buvo beveik ketvirtadalis (24 proc.). Trečdaliui pradinių klasių mokinių patinka fiziniu požiūriu aktyvi veikla (judejjimas ir sporto būrelių lankymas), o apie pusė apklaustų vaikų mėgsta pasyvaus pobūdžio veiklas (meninę veiklą, lankyti pasyvaus pobūdžio būrelius, žiūrèti televizorių, žaisti kompiuterinius žaidimus, skaityti knygas). Per dieną pasyvioms veikloms vaikai vidutiniškai skiria $-3,4$ val. vaikų nuomone, o-4,3 val. tèvų nuomone. Aktyviai fizinei veiklai, vaikų nuomone, skiriamos 2,2 val., tėvų nuomone $-1,8$ valandos. Tik apie dešimtadalis šeimų užsiima aktyvia fizine veikla ir sportuoja kartu. Taigi vaikų kartu su šeima praleidžiamas laisvalaikis nėra pakankamai aktyvus.

Adresas susirašinèti: n.strazdiene@gmail.com

Gauta 2017-11-06 